\title{
Protective roles of natural IgM antibodies
}

\section{Caroline Grönwall, Jaya Vas and Gregg J. Silverman*}

New York University School of Medicine, New York, NY, USA

\section{Edited by:}

Thomas L. Rothstein, The Feinstein Institute for Medical Research, USA

\section{Reviewed by:}

Kishore Alugupalli, Thomas Jefferson University, USA

John D. Colgan, University of lowa, USA

\section{*Correspondence.}

Gregg J. Silverman, New York

University School of Medicine, 450

East 29th Street, 8th Floor, Room

804, New York, NY 10016, USA.

e-mail: gregg.silverman@nyumc.org
Antibodies are a vital part of the armamentarium of the adaptive immune system for the fine-tuning of the recognition and response to foreign threats. However, in health there are some types of antibodies that instead recognize self-antigens and these contribute to the enhancement of primitive innate functions. This repertoire of natural IgM antibodies is postulated to have been selected during immune evolution for their contributions to critical immunoregulatory and housekeeping properties. The clearance of dying cells is one of the most essential responsibilities of the immune system, which is required to prevent uncontrolled inflammation and autoimmunity. In the murine immune system, natural IgM antibodies that recognize apoptotic cells have been shown to enhance the phagocytic clearance of dead and dying cells and to suppress innate immune signaling pathways. In the mouse, natural IgM are often the products of B-1 cell clones that arise during immune development without an absolute requirement for exogenous antigenic stimulation. In patients with systemic lupus erythematosus, IgM autoantibodies, which bind to neo-epitopes on apoptotic cells, have been demonstrated to be present at significantly higher levels in patients with lower disease activity and with less severe organ damage. While certain specificities of IgM autoantibodies correlate with protection from lupus renal disease, others may convey protective properties from lupus-associated atherosclerotic cardiovascular disease. New and unexpected insights into the functional roles of IgM antibodies are still emerging, especially regarding the functions of natural antibodies. Herein, we review recent progress in our understanding of the potential roles of natural IgM autoantibodies in the regulation of immune homeostasis and for protection from autoimmune and inflammatory diseases.

Keywords: B-1 cells, autoreactive antibodies, autoimmune disease, clearance of apoptotic cells, immune homeostasis, autoantibody, inflammation

\section{INTRODUCTION}

While the innate immune system is more ancient, the adaptive immune system first arose more recently with the appearance of cartilaginous fish (reviewed in Dooley and Flajnik, 2006). IgM is the most evolutionary conserved antibody isotype, and present in all vertebrates, and it is also the earliest isotype to be expressed during immune development. In the mouse up to $80 \%$ of circulating IgM derive from B-1 cells (Baumgarth et al., 1999), which is a distinct B-cell subset that is uncommon in peripheral lymphoid tissues but highly represented amongst mononuclear cells in the peritoneal and pleural cavities (Hayakawa et al., 1986). While the largest population of mature B cells, follicular B cells (also termed B-2 cells), are primarily responsible for T-cell dependent immune responses, both marginal zone B cells and B-1 cells represent mature lymphocyte subsets that are involved in innate-like responses, with more rapid responses to non-protein antigens. Although there may be some overlap in their functional roles, B1 cells and marginal zone B cells have many distinct phenotypic and functional features (Martin et al., 2001; Martin and Kearney, 2002). In a recent study, precursors for B-1 cells were also found in adult murine spleen, and these significantly differed in their phenotypes from those of marginal zone B cells and conventional follicular B cells (Ghosn et al., 2011). There may also be some plasticity in the differentiation capacity of the progenitors for these three major types of mature B cells (Tung et al., 2006).

The unique functions of B- 1 cells are linked to their specialized surface phenotype and signaling thresholds, and their capacity to be recruited into $\mathrm{T}$-cell independent responses following challenge with certain non-protein antigens (reviewed in Baumgarth, 2011). In fact, in the mouse B-1 cells two subsets with distinct surface phenotypes have been identified, B- $1 \mathrm{a}$ and B-1b. B- 1 cells are a major source of antibodies that are constitutively secreted without prior immune activation (Baumgarth et al., 2005; Holodick et al., 2010). These secreted immunoglobulins have been termed "natural antibodies" as these types of antibodies may be present from birth without external antigenic exposure, which stand in contrast to "immune" antibodies that arise after specific immune exposure or antigenic challenge. In mice, secreted natural IgM is generated by B-1 cells predominantly in the spleen, and to a lesser extent in the bone marrow. A recent report argued that splenic IgM-producing B-1 cells are distinctly different from the B-1 cells found in the peritoneal cavity that only express very small amounts of secreted IgM (Choi et al., 2012), although this topic remains controversial. Mice raised under germ-free conditions, and fed a diet that is free from foreign antigens, still develop a normal IgM natural 
antibody repertoire, which suggests that other factors are involved in the clonal selection of B-1 cells (Bos et al., 1989; Haury et al., 1997).

At a genetic and structural level, the murine B-1 cell pool, which is a major source of natural antibodies, is enriched for a recurrent repertoire that includes an overrepresentation of $\mathrm{V}_{\mathrm{H}} 11$ and $\mathrm{V}_{\mathrm{H}} 12$ heavy chain variable region rearrangements, and preferential $\mathrm{H}-\mathrm{L}$ chain pairing, that have been associated with an autoreactive binding specificity (Hardy et al., 1989; Mercolino et al., 1989; Wang and Clarke, 2004; Rowley et al., 2007). Natural antibodies from B-1 cells are reported to be often encoded by germline variable gene segments unaffected by somatic hypermutation (Kantor et al., 1997). The repertoire of murine B-1 cell derived antibodies is also reported to less commonly include rearrangements with nontemplated nucleotide additions (i.e., $\mathrm{N}$-insertions) in their $\mathrm{V}-\mathrm{D}$ and D-J junctions (Herzenberg et al., 2000). An absence of Ninsertions in the CDR3 associated splice sites may reflect a clonal origin of B-1 cell precursors in the fetal liver, an early site of Blymphogenesis in which murine B-cell precursors do not express the terminal deoxynucleotidyl transferase (TdT) for this somatic mechanism of the Ig repertoire.

Host defenses have also been shown to benefit from B1 cell responses to common microbial pathogens (Baumgarth et al., 2005). Yet, there is mounting evidence that natural IgM antibodies also contribute to critical innate immune functions involved in the maintenance of tissue homeostasis. As described in the following sections, these functions include augmenting the clearance of apoptotic cells and the reinforcement of mechanisms involved in protection from the development of autoimmune disease (Chen et al., 2009a,b; reviewed in Silverman et al., 2009).

\section{AUTOREACTIVITY OF NATURAL ANTIBODIES}

The immune system is tightly regulated at several checkpoints during lymphocyte differentiation by strict mechanisms that weed out clones with the potential for pathogenic self-reactive responses. These checkpoints serve to prevent the development of autoimmune disease. However, it is now accepted that certain types of autoreactive immune cells and antibodies are common in health, and accumulating evidence suggest that autoreactive antibodies can play important roles in tissue homeostasis. While in some cases the binding interactions of natural IgM clones are of rather low affinity, and the same antibody can display polyreactivity for a range of ligands (Casali and Notkins, 1989), another type of natural antibody can display great mono-specificity for its binding self-ligand.

A major set of natural antibodies specifically binds to oxidationassociated neo-determinants that become exposed on apoptotic cells (Chou et al., 2009), but which are not displayed on healthy cells. Despite the complexity of the apoptotic cell membrane, two types of neo-self epitopes appear to dominate in vivo murine immune responses to apoptotic cells; the headgroup of oxidized lipids, phosphorylcholine (PC), and the small oxidationassociated determinant, malondialdehyde (MDA), which is chemically active and can become an adduct on proteins. Recent studies have shown that more than $50 \%$ of the splenic IgM-secreting cells induced by infusions of apoptotic cells recognize these two sets of epitopes (Chen et al., 2009b). In addition, studies have shown that other types of antibodies can instead bind unrelated apoptotic cell associated neo-epitopes, which include cardiolipin, phosphatidylserine, and Annexin IV (Tuominen et al., 2006; Fu et al., 2007; Kulik et al., 2009; Kim, 2010).

The best characterized type of natural antibody has the capacity for specific immune recognition of phosphorylcholine (PC)containing antigens, which are present and accessible on apoptotic cell membranes and in oxidized LDL, as well as represent the immunodominant epitope in the pneumococcal bacterial cell wall polysaccharide (Shaw et al., 2000; Friedman et al., 2002; Chou et al., 2009). In host cell membranes, PC represents a head group in neutral phospholipids, such as phosphatidylcholine. However, in healthy cells, the PC head group is held in a conformation that makes it inaccessible for recognition and binding by antibodies, while during apoptotic death oxidative modifications can result in changes in the overall conformation of the molecule that enable the immune recognition of the PC-containing phospholipid determinants.

In the murine immune system, of the many hundreds of inherited $\mathrm{V}_{\mathrm{H}}$ gene segments, most natural antibodies to PC utilize the $\mathrm{V}_{\mathrm{H}} \mathrm{S} 107.1$ gene, which is rearranged to encode for the above described deep antigen-binding cleft for the PC moiety that is highly prevalent in the B-1 repertoire. As a consequence, otherwise immunocompetent mice, which have been engineered to be deficient in this single $V_{H}$ gene segment, have highly impaired immune responses to the PC determinants on both apoptotic cells and on bacteria (Mi et al., 2000; Chen et al., 2009b). Crystallographic studies, which have elucidated the structural basis for the formation of the PC binding site of this type of natural antibody, have therefore demonstrated how evolutionary forces can select for an optimized innate-like B-cell antigen receptor (BCR) antigen-binding site that is highly and recurrently expressed within the murine B-1 repertoire (Satow et al., 1986).

There is also a distinct set of natural antibodies that binds to determinants that arise on erythrocytes during their senescence or after red cell enzymatic treatment with a protease, bromelain (Cox and Hardy, 1985; Mercolino et al., 1986; Hardy and Hayakawa, 2005). Because these cells are devoid of nuclei as well as mitochondria, the aging, or senescence of mature red cells is not associated with membrane modifications induced by caspasedependent apoptosis-associated pathways that affect other types of cells in the body. Instead, red cell membranes appear to undergo a different type of senescence associated changes, which can be recognized by natural antibodies. These anti-red cell antibodies are reported to recognize determinants that involve the entire phosphatidylcholine $(\mathrm{PtC})$ molecule in the outer cell membranes, and not associated with isolated PC-containing antigens. Yet, it has been unclear whether these binding interactions involve a special type of modification of PtC. Alternatively, these interactions may also result from the loss of erythrocyte membrane-associated proteins, which thereby increase the accessibility of antibodies to PtC-containing determinants. In summary, in the mouse there are two major and distinct subsets of autoreactive natural antibodies, which recognize senescent red cells, or other types of cells undergoing apoptotic death. These different antibody sets are postulated to 
fulfill different functional roles, which together reinforce immune homeostasis (see below).

The antibody repertoire of B-1 cells appears to arise due to specialized differences in the signaling thresholds of this lymphocyte subset, and the BCR mediated responses in B-1 cells have different cellular fate outcomes than occur for follicular B cells. Encounter of a B-1 cell precursor with its cognate self-antigen may result in a positive selection process that leads to clonal selection and expansion, while such encounters by a conventional follicular B-cell commonly result in activation-associated cell death (Pillai et al., 2004). Such a B-1 cell associated process has been documented in vivo with primary B cells that express an Ig-transgene that encodes for recognition of an epitope on the glyco-conjugate associated Thy-1 determinant (Hayakawa et al., 1999). Taken together, the data show that while some B-1 cell derived natural antibodies are inherently polyreactive, other B1 cell clones display highly selective binding specificities. As a consequence, the repertoire of IgM natural autoantibodies is not randomly generated but instead includes highly represented recurrent clonotypes. Studies in the mouse have been interpreted as evidence that the early B-cell repertoire arises following a developmentally determined sequence (Perlmutter et al., 1985), which we argue has been selected in part to play beneficial homeostatic functions. Furthermore, this process of B-1 cell associated positive selection may also explain the reported relative homogeneity in the IgM natural autoantibody repertoire expressed between different individual mice of the same strain (Seidl et al., 1997; Vasconcellos et al., 1998), and may also be responsible for the strikingly uniform natural IgM binding reactivity profiles reported in human newborns (Merbl et al., 2007; Madi et al., 2009).

The features of autoreactive IgM natural antibodies that arise in a healthy individual may differ fundamentally from the highaffinity somatically mutated IgG autoantibodies that can arise during an autoimmune disease, in part because B-1 cell products are not commonly recruited into $\mathrm{T}$-cell dependent germinal center reactions. Furthermore, functional properties of IgM antibodies are also distinct because the $\mu$ constant region of IgM is devoid of the functional capacities for the triggering of activating Fc $\gamma$ receptors associated with certain IgG subclasses. In health, the B-1 cell responses are generally limited to switching to an IgG subclass that has little or no Fc $\gamma$ R binding activity (i.e., murine IgG3).

B-1 cells are reported to be a major contributor to the gutassociated lymphoid tissues, often following class switch of the constant region to IgA (Kroese and Bos, 1999; Stoel et al., 2005). B-1 cell derived IgA antibodies have been shown to aid the clearance of microbes from the gut lumen (Kroese et al., 1989), and IgA secreted into the gut can therefore influence the relative representation of microbial species within the microbiome. Using a systems biology approach, Matzinger and co-workers recently described a three-way interaction between IgA responses in the gut, the representation of microbiota species, and the functional properties and activation level of intestinal epithelium (Shulzhenko et al., 2011). The intertwined dependence of these different components of host defenses with the internal microbiota milieu are speculated to determine overall immune competency, and no doubt represents a topic that will merit further examination in the future.

\section{PROTECTION AGAINST INFECTION}

Natural IgM antibodies are reported to recognize a wide range of different microbial components, which include viral antigens and bacterial toxins (Ochsenbein et al., 1999). The broad reactivity pattern of the natural antibodies may therefore help to protect against a variety of pathogens not previously encountered. Due in part to the high avidity of polymeric IgM, these may contribute to the initial immune defense and to the control of invading pathogens until the immune system has time to launch a specific adaptive response (reviewed in Baumgarth et al., 2005). In certain cases, the B-1 expressed IgM antibodies have been shown to directly neutralize or inhibit pathogens as well as aid the initiation of adaptive immune responses from follicular B cells, which together play critical roles in protection against bacterial and viral infections (Boes et al., 1998; Ochsenbein et al., 1999; Baumgarth et al., 2000; Haas et al., 2005; Zhou et al., 2007). As mentioned above, the repertoire of natural antibodies also enables recognition of non-protein selfantigens such as phosphorylcholine (PC), phosphatidylcholine (PtC), and carbohydrate determinants, and that in some cases these antibodies are capable of cross-reactivity with structurally related epitopes on microbes. Due to the importance of autoreactive antibodies in apoptotic cell clearance, the self-recognition properties of these antibodies may be just as important for the host as pathogen recognition.

\section{INNATE IMMUNE FUNCTION AND THE PHAGOCYTIC CLEARANCE OF APOPTOTIC CELLS}

One of the most fundamental functions of the immune system is the recognition and removal of the large number of dying cells that are continually generated in our bodies. Even in adults, hundreds of billions of cells die each day and are continually replaced. Cells dying from apoptosis, a form of programmed cell death, undergo an active energy-dependent cascade that is highly controlled, resulting in cell shrinkage, protein cleavage, DNA breakdown, and extensive plasma membrane changes specific for apoptosis. These apoptotic cells are cleared by phagocytosis by macrophages in a process that has been termed efferocytosis, for taking out the dead (deCathelineau and Henson, 2003). This mechanism is required for normal tissue homeostasis as it prevents the accumulation of cells that would otherwise progress to secondary necrosis and the release of autoantigens and pro-inflammatory factors such as the high-mobility group box 1 (HMGB-1) protein (Scaffidi et al., 2002), uric acid, heat-shock proteins, and S100 proteins (Hofmann et al., 1999; Basu et al., 2000; Scaffidi et al., 2002; Shi et al., 2003; reviewed in Kono and Rock, 2008). While apoptotic cells do not themselves pose a risk to the host, their cell membranes in fact contain components that can be anti-inflammatory. Hence, in vivo treatment with apoptotic cells have been shown to inhibit inflammatory responses in murine models (Huynh et al., 2002; Gray et al., 2007; Chen et al., 2009a).

There are many factors produced by the innate immune system that act as what have been termed "eat-me signals" (i.e., tags for apoptotic cells for recognition by immune cells), which include $\mathrm{C} 1 \mathrm{q}$, mannose binding lectin (MBL), collectins, and pentraxins (reviewed in Ravichandran and Lorenz, 2007; Devitt and Marshall, 2011). Yet, certain B-1 cell clones secrete IgM natural antibodies specific for determinants that become exposed on apoptotic cells, 
but which are not present on healthy cells (Shaw et al., 2003), and there is increasing evidence that the specific recognition of dying cells by natural antibodies can play an important role in integrating and coordinating these processes (reviewed in Silverman et al., 2009). The essential role of IgM for the clearance of apoptotic cells has been well established (Ogden et al., 2005; Quartier et al., 2005; Chen et al., 2009a,b) and incubation with polyclonal IgM has been demonstrated to also promote clearance of apoptotic microparticles released from dying cells (Litvack et al., 2011) as well as enhance the phagocytosis of apoptotic cells in the lungs by alveolar macrophages (Litvack et al., 2010). Indeed, mice engineered to be deficient in IgM have defects in the clearance of apoptotic cells (Chen et al., 2009a; Notley et al., 2011) and have increased susceptibility to develop a lupus-like syndrome with expression of IgG autoantibodies to nuclear antigens (Boes et al., 2000). Importantly, recent studies have shown that there are certain $\operatorname{IgM}$ clones that are essential for mediating the immunoregulatory effects of apoptotic cells (Chen et al., 2009a,b). Natural IgM has also recently been reported to enhance apoptotic cell phagocytosis in the marginal zone of the spleen and promote IL-10-secreting B and T cells that restrain the development of inflammation (Notley et al., 2011).

In vitro and in vivo studies have shown that a murine monoclonal IgM produced by a B-1 cell derived cell line, with identical antibody gene usage to the classic T15 clone, which binds to PC determinants on apoptotic cells, also has potent anti-inflammatory properties (Chen et al., 2009a,b). This clone produces a prototypic natural antibody that expresses non-hypermutated canonical $\mathrm{V}_{\mathrm{H}} \mathrm{S} 107.1$ and $\mathrm{V}_{\mathrm{K}} 22 \mathrm{~L}$ chain rearrangements, and T15 clonotypic B-1 cells spontaneously arise in the first week of life even under germ-free conditions (Sigal et al., 1975; Gearhart et al., 1977). The binding of IgM anti-PC to apoptotic cells leads to the formation of complexes with the recruitment of the early complement factors involved in ligand recognition, C1q, and the structurally related MBL (Chen et al., 2009a,b). As mentioned above, C1q and MBL can represent "eat-me" signals for innate immune cells to recognize and respond to apoptotic cell membranes (Korb and Ahearn, 1997; Navratil et al., 2001; Ogden et al., 2001; Stuart et al., 2005). The binding interactions of the complement molecules directly with apoptotic cell surface are not fully characterized, but in one system C1q was shown to directly interact with determinants such as phosphatidylserine (PS; Paidassi et al., 2008). As reported recently, in some settings, this deposition of $\mathrm{Clq}$ onto apoptotic cells can be immunomodulatory and inhibit the secretion of pro-inflammatory cytokines (Fraser et al., 2009). Recent studies have shown that these properties may be amplified when higher levels of $\mathrm{C} 1 \mathrm{q}$ are recruited by $\operatorname{IgM}$ that is complexed with apoptotic cells (Chen et al., 2009a,b). The binding of IgM to apoptotic cells may similarly enhance MBL recruitment that leads to the same anti-inflammatory effects (Chen et al., 2009b). These findings are consistent with evidence that MBL-deficient mice display defective apoptotic cell clearance although without autoimmune phenotype (Stuart et al., 2005). In mice, C1q deficiency is also associated with a clearance defect and it can contribute to accelerated disease in lupus-prone strains. Moreover, in humans $\mathrm{Clq}$ deficiency is associated with severe lupus-like autoimmune disease (reviewed in Botto and Walport, 2002; Lewis and Botto, 2006). These phenotypes have been suggested to result in part from impaired capacity for apoptotic cell clearance.

Binding of polymeric IgM to a highly valent antigen, as can occur with interactions with the surface of an apoptotic cell, alters the conformation, or accessibility of $\mu$ constant region determinants, which enables binding of the large polymeric macromolecule, C1q. In turn, this complexed C1q may become available to interact with $\mathrm{Clq}$ receptors, and the complex can also initiate the capacity for associated $\mathrm{C} 1$ esterases to activate downstream complement components (Perkins et al., 1991; Czajkowsky and Shao, 2009). While C1q in plasma is directly and preferentially deposited on late apoptotic and secondary necrotic cells, IgM that recognize apoptotic cell membranes can facilitate the enhanced recruitment of $\mathrm{Clq}$ and thereby mediate the phagocytosis of cells at an earlier stage of apoptosis than incubation with $\mathrm{C} 1 \mathrm{q}$ alone. Similarly $\mathrm{MBL}$ molecules, which are structurally related to $\mathrm{Clq}$ and share a common evolutionary origin, can also bind directly to an apoptotic cell membrane, and these polymeric molecules display enhanced recruitment by some anti-apoptotic cell $\operatorname{IgM}$ antibodies that contain high mannose glycoconjugates (Arnold et al., 2006; Chen et al., 2009a). Recent studies suggest that C1q and MBL serve as bridging molecules that trigger specialized phagocyte functions for engulfment and clearance of apoptotic cells, by a pathway that does not require downstream activation of the complement cascade (Chen et al., 2009a,b).

Complexes formed of apoptotic cells with the above described anti-PC IgM antibodies, or with polyclonal IgM that contains a subset of related antibodies, can also result in strong suppression of in vivo and in vitro inflammatory responses, including those induced by ligands for Toll-like receptors (TLRs; Chen et al., 2009a). This natural antibody mediated regulatory process, which requires recruitment of $\mathrm{Clq}$ or MBL, involves the blockade of TLR-mediated pro-inflammatory signaling by inhibition of MAPK pathways (unpublished). We hypothesize that these IgM antibody interactions facilitate the formation of a synapse between the apoptotic cell and the phagocyte (see Figure 1). This complex enhances the immunoregulatory properties of apoptotic cell membranes by increasing interactions between the immune cell and apoptotic cell determinants. This synapse is postulated to involve both soluble factors and receptors that stabilize the interactions between these cells and receptors, initiating specific signaling events that result in engulfment and which trigger active antiinflammatory responses. Our recent studies have found evidence that the anti-inflammatory potential of the anti-apoptotic cell IgM is mediated through a fundamental regulatory immunosuppressive pathway. These findings suggest that the circulating natural antibodies that target apoptotic cells serve not only to remove apoptotic cells but may also act as direct immunoregulators.

\section{NATURAL IgM IN MURINE MODELS OF INFLAMMATORY DISEASE}

Vaccinations that induce elevated levels of anti-PC IgM antibodies have been shown to halt the progression of atherosclerosis in hypercholesterolemic LDL receptor-deficient mice (Binder et al., 2003). More recent studies have confirmed these findings, as polyclonal natural IgM treatment reduced atherosclerosis and 


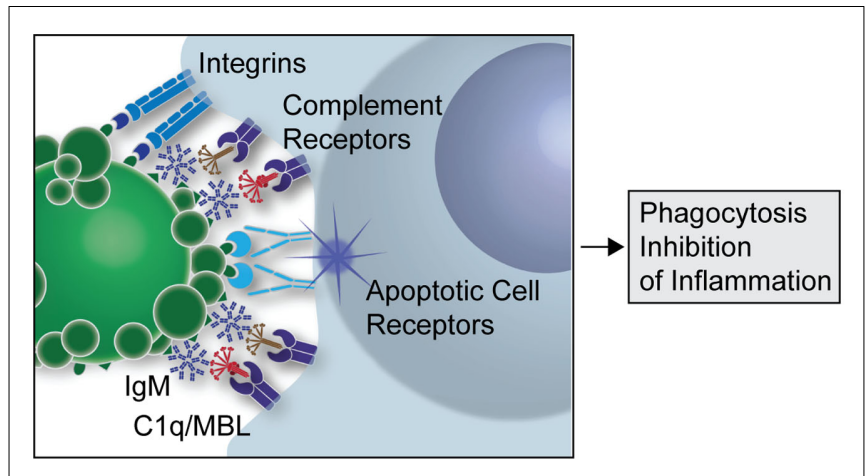

FIGURE 1 | Postulated contribution of natural IgM in apoptotic cell clearance. Schematic overview of how natural lgM binding to apoptotic cells may facilitate the formation of an apoptotic synapse between the apoptotic cell or microparticle and the phagocyte, and this leads to enhanced recruitment of the complement recognition factors, C1q and MBL. A large number of other ligands and receptors have been suggested to promote phagocytosis of apoptotic cells, which are not shown in this simplified model.

lowered levels of potentially pathogenic CD4 $+\mathrm{T}$ cells in hypercholesterolemic ApoE-/- mice (Cesena et al., 2012). Studies have also shown that treatments with monoclonal IgM antidsDNA antibodies can delay the onset of lupus-like disease in $(\mathrm{NZB} \times \mathrm{NZW}) \mathrm{F} 1$ mice (Werwitzke et al., 2005) and lower disease activity in MRL/lpr mice (Jiang et al., 2011). Moreover, treatments with a recombinant self-reactive IgM was recently shown to reduce levels of pro-inflammatory $\mathrm{T}_{\mathrm{H} 17}$ cells and autoimmune disease in Fc $\gamma$ RIIB/TLR9 deficient mice (Stoehr et al., 2011).

Studies of mice that lack the capacity to produce serum IgM have helped to elucidate the immunomodulatory roles of secreted IgM. As mentioned above, in predisposed animals the absence of IgM leads to enhanced production of pathogenic IgG autoantibodies and autoimmune disease, and in hyperlipidemic mice IgM-deficiency predisposes to the development of accelerated atherosclerosis (Boes et al., 2000; Ehrenstein et al., 2000; Lewis et al., 2009). While it is possible that in these settings, natural IgM directly acts by neutralization of harmful molecules, increasing evidence suggest that the observed protective properties may instead derive from a subset of natural IgM that specifically recognize apoptotic cells, which leads to enhanced efferocytosis and an active anti-inflammatory response. As described above, in vivo treatment with the IgM natural antibody to the PC head group in oxidized lipids on apoptotic cells strongly inhibited inflammatory responses in lymphoid tissues to TLR agonists (Chen et al., 2009a). In addition, infusions with this anti-apoptotic cell antibody suppressed the development of collagen induced arthritis (CIA), a murine model with many of the key features of rheumatoid arthritis, and also suppressed the development of disease in the anti-collagen antibody passive transfer model (Chen et al., 2009a).

\section{RECEPTORS FOR IgM ANTIBODIES}

The potential roles of different cellular receptors for IgM are a topic of active investigation. IgM can bind either to the $\mathrm{F} c \alpha / \mu \mathrm{R}$ or the polymeric Ig receptor (Shibuya et al., 2000; Kaetzel, 2005), and both of these receptors recognize $\operatorname{IgM}$ as well as $\operatorname{IgA}$. Although the pathways are yet to be fully determined, the $F c \alpha / \mu R$, expressed on B cells and follicular dendritic cells, has recently been demonstrated to negatively regulate immune responses against T-independent antigens, which may have implications for the functions of natural antibodies (Honda et al., 2009). Fc $\alpha / \mu \mathrm{R}$ is also upregulated on human macrophages following Toll-like receptor 4 (TLR4) stimulation (Feng et al., 2010). In addition, CD22 (Siglec-2), an inhibitory co-receptor on B cells, binds to sialic acid containing glycoconjugates on soluble IgM, and the TOSO/Fas apoptotic inhibitory molecule 3 (FAIM3) has recently been identified as a distinct Fc receptor for IgM expressed on B cells (Shima et al., 2010). TOSO/FAIM3 may play a role in immune surveillance and B-cell activation as it acts as an endocytic receptor and internalizes bound $\operatorname{IgM}$ and then transport these complexes into lysosomes for degradation. TOSO has also been shown to be highly expressed on chronic lymphocytic leukemia (CLL) cells, wherein TLR stimulation induces strong downregulation of expression levels (Vire et al., 2011). It is currently unknown whether these receptors affect the activity of B-1 cells and the functional properties of soluble natural IgM antibodies.

\section{HUMAN NATURAL IgIM AND THEIR PROTECTIVE PROPERTIES}

Until recently, the identification and characterization of the human B-1 subset expressing natural antibodies has been elusive. However, Griffin et al. (2011) have identified a subset of CD43+ CD27+ mononuclear cells as B-1 cell analogs, which spontaneously produce natural IgM anti-PC and these cells may be the predominant source of constitutively produced human IgM. Further supporting the importance of these cells during immune development, these cells were found both in healthy adult and umbilical cord blood. These findings are consistent with evidence that human natural IgM-autoreactive antibodies are highly represented in the sera of healthy adults and newborn babies (Merbl et al., 2007). In fact, studies have shown that up to $50 \%$ of peripheral blood B cells in newborns and 15-20\% of circulating B cells in adults are polyreactive and potentially express some level of autoreactivity (Chen et al., 1998). Importantly, a major proportion of natural IgM antibodies in human cord blood recognize oxidation-specific epitopes that can mediate binding of apoptotic cells (Chou et al., 2009).

IgM antibodies to the oxidation-associated epitopes, PC, and MDA, which arise on apoptotic cells, are also commonly expressed in healthy humans (Silverman et al., 2008). In clinical surveys, while levels of IgM anti-PC can vary more than 100-fold between different persons (Padilla et al., 2004), serum IgM anti-PC reactivity detected in ELISA assays strongly correlated with the level of IgM in the sera that binds to apoptotic cells (Padilla et al., 2004). Furthermore, IgM anti-PC in healthy adults was shown to be generally stable over a 6-week survey period (Padilla et al., 2004). It can be hypothesized that in many acute inflammatory conditions there may be a milieu associated with an acute accumulation of higher levels of apoptotic cells, which would result in reduced levels of IgM anti-PC due to consumption of these circulating, primarily intravascular, molecules. In support, following isolated limb perfusion with TNF-alpha for local 
treatment of solid tumors, levels of circulating IgM anti-PC were decreased by up to $60 \%$ at $48 \mathrm{~h}$ after treatment (Padilla et al., 2004).

Studies of SLE discordant twins have shown that higher levels of IgM anti-PC are often present in the healthy twin, which was speculated to represent how IgM antibodies to apoptotic cells may provide protection from autoimmune disease in genetically predisposed individuals (Silverman et al., 2008). Yet, in surveys of 120 unrelated patients with SLE of diverse ethnic background, although there was great variability between individuals, lupus patients were shown to have significantly higher levels of antiPC antibodies compared to unrelated healthy controls, which was proposed to reflect a compensatory mechanism to the higher state of systemic inflammation and increased chronic immune exposure to apoptotic cells (Gronwall et al., 2012). Significantly, higher levels of PC anti-IgM correlated with lower disease activity and organ damage (Gronwall et al., 2012), which is consistent with an earlier report in a smaller Swedish cohort (Su et al., 2008). These data therefore support the hypothesis that IgM anti-PC antibodies may play protective roles in lupus.

Longitudinal surveys of patients with SLE have also demonstrated that levels of IgM anti-PC antibodies decreased by a mean $50 \%$ decrease over a 15 -year period, while total serum $\operatorname{IgM}$, and levels of other IgM antigen-binding specificities, did not significantly change (Gronwall et al., 2012). However, it is currently uncertain whether this reflects the natural history of the disease, or perhaps the cumulative impact of therapeutic interventions. Nonetheless, these findings are consistent with the recent results that the representation of human B-1 cells in the circulation generally declines in normal individuals with aging (Griffin et al., 2011). Taken together, these findings may suggest that the capacity of some individuals to produce certain types of protective IgM antibodies may wane overtime.

While IgM is the predominant isotype of circulating human anti-PC antibodies, IgG anti-PC are also commonly present. Notably, in both healthy individuals and SLE patients, IgG anti-PC is predominantly of the IgG2 subclass that is associated with a lower capacity for the triggering by immune complexes of activating $\mathrm{F} c \gamma \mathrm{R}$. Due to the report that the specificity of a murine monoclonal antibody can be changed from PC to DNA by a single point mutation (Diamond and Scharff, 1984), there has been speculation regarding the potential for antigenic cross-reactivity of such natural antibody responses, which could have a negative influence in lupus predisposed individuals (Diamond et al., 1992; Peng et al., 2005). However, this topic has been directly investigated in patients with lupus, and no correlation was found between levels of anti-PC antibodies and anti-dsDNA antibodies. In fact, levels of IgG anti-PC antibodies in these patients did not correlate with any clinical disease manifestations, or with changes in other serologic markers such as C3, C4, that were measured (Gronwall et al., 2012).

Natural antibodies to apoptotic cells may also be relevant to the pathogenesis of a wide range of diseases. Many inflammatory conditions, such as atherosclerosis and chronic pulmonary disease, are associated with chronically increased levels of apoptotic cells, either due to increased production or impaired apoptotic clearance. We would argue that in these settings higher levels of IgM anti-apoptotic cell antibodies, through enhancing apoptotic clearance and the dampening of inflammation, may also provide benefits. We have found that higher levels of IgM anti-PC correlate with protection from cardiovascular events in patients with lupus (Gronwall et al., 2012), which was consistent with findings in a smaller study (Su et al., 2008). Furthermore, Frostegård and co-workers have also shown that low levels of IgM anti-PC antibodies in patients with lupus correlate with occurrence of detectable atherosclerotic plaques by carotid ultrasound (Anania et al., 2010). Low levels of IgM anti-PC have also been associated with increased occurrence of stroke (Fiskesund et al., 2010), heart attack (Gronlund et al., 2009), and symptomatic atherosclerotic cardiovascular disease in men over 60 years of age (de Faire and Frostegard, 2009), as well as Alzheimer's disease (Eriksson et al., 2010). Higher levels of IgM and IgG binding

Table 1 | Specific IgM antibody levels correlate with protection from human disease.

\begin{tabular}{|c|c|c|c|}
\hline IgM specificity & $\begin{array}{l}\text { Present in } \\
\text { health }\end{array}$ & $\begin{array}{l}\text { Protective properties } \\
\text { in human disease }\end{array}$ & Reference \\
\hline PC & Yes & $\begin{array}{l}\text { SLE disease activity and organ damage } \\
\text { Atherosclerotic cardiovascular events in SLE } \\
\text { Myocardial infarction and stroke } \\
\text { Alzheimer's disease } \\
\text { Mortality in patients undergoing hemodialysis }\end{array}$ & $\begin{array}{l}\text { Carrero et al. (2009), de Faire and Frostegard (2009), Gronlund et al. } \\
\text { (2009), Anania et al. (2010), Eriksson et al. (2010), Fiskesund et al. } \\
\text { (2010), Gronwall et al. (2012) }\end{array}$ \\
\hline Oxidized LDL* & Yes & $\begin{array}{l}\text { Atherosclerosis } \\
\text { Cerebral small vessel disease }\end{array}$ & $\begin{array}{l}\text { Fukumoto et al. (2000), Karvonen et al. (2003), Garrido-Sanchez et al. } \\
\text { (2010), Rouhl et al. (2010) }\end{array}$ \\
\hline$\beta 2-\mathrm{GPI}$ & No & $\begin{array}{l}\text { SLE organ damage } \\
\text { Renal disease in SLE }\end{array}$ & Mehrani and Petri (2011), Gronwall et al. (2012) \\
\hline $\mathrm{CL}$ & No & $\begin{array}{l}\text { Renal disease in SLE } \\
\text { Cardiac events in postinfarction patients }\end{array}$ & Bili et al. (2000), Gronwall et al. (2012) \\
\hline dsDNA & No & $\begin{array}{l}\text { Renal disease in SLE } \\
\text { SLE disease activity }\end{array}$ & Witte et al. (1998), Forger et al. (2004), Gronwall et al. (2012) \\
\hline
\end{tabular}

${ }^{*}$ Oxidized LDL is a large complex containing many epitopes including PC and MDA. 
to oxidized LDL, a complex macromolecule that expresses the PC epitope, have been found to correlate with a lower burden of atherosclerosis, as measured by carotid artery intima-media thickness by ultrasound (Fukumoto et al., 2000; Karvonen et al., 2003).

Higher levels of IgM antiphospholipid antibodies that bind to beta-2-glycoprotein I ( $\beta 2$-GPI) and cardiolipin in lupus patients correlated with less frequent renal disease manifestations (Mehrani and Petri, 2011; Gronwall et al., 2012). Similarly, although IgGantibodies to dsDNA are the hallmark of lupus and are often associated with lupus nephritis, higher levels of IgM anti-dsDNA, and a lower ratio of $\operatorname{IgG}$ to IgM anti-dsDNA are instead negatively associated with the occurrence of glomerulonephritis in SLE patients (Witte et al., 1998; Forger et al., 2004; Witte, 2008; Gronwall et al., 2012; see Table 1). It may therefore be relevant that anti-dsDNA, anti-cardiolipin, and anti- $\beta 2$-GPI antibodies have been shown to bind apoptotic cells (Rovere et al., 1998; Sorice et al., 2000; Cocca et al., 2001; Wellmann et al., 2005). Microarray studies of SLE patients have also shown that the presence in a lupus patient of a diverse autoreactive IgM profile, which was interpreted as representing higher levels of cross-reactive IgM antibodies, was correlated with less active lupus disease ( $\mathrm{Li}$ et al., 2005). The cellular origins and regulation of IgM with these specificities, and their relationship to B-1 cells that produce anti-PC natural antibodies merit further investigation.

\section{CONCLUDING REMARIS}

It has become clear that natural IgM can play crucial roles in the immune system and recent studies have highlighted the importance of IgM as immunomodulatory and protective factor in inflammatory and autoimmune disease. While the binding specificities and constant region-associated effector functions of some IgG autoreactive antibodies convey pathogenic properties, there are also specific IgM self-reactive antibodies that may instead have beneficial effects, protecting from uncontrolled inflammation, and

\section{REFERENCES}

Anania, C., Gustafsson, T., Hua, X., $\mathrm{Su}$, J., Vikstrom, M., De Faire, U., Heimburger, M., Jogestrand, T., and Frostegard, J. (2010). Increased prevalence of vulnerable atherosclerotic plaques and low levels of natural IgM antibodies against phosphorylcholine in patients with systemic lupus erythematosus. Arthritis Res. Ther. 12, R214.

Arnold, J. N., Dwek, R. A., Rudd, P. M., and Sim, R. B. (2006). Mannan binding lectin and its interaction with immunoglobulins in health and in disease. Immunol. Lett. 106, 103-110.

Basu, S., Binder, R. J., Suto, R., Anderson, K. M., and Srivastava, P. K. (2000). Necrotic but not apoptotic cell death releases heat shock proteins, which deliver a partial maturation signal to dendritic cells and activate the

contributing to the maintenance of the immunological balance. The efficient disposal of dead cells is one of the most primitive and pivotal functions of the immune system. Recurrent natural antibody IgM clones have therefore developed specialized functions, with a higher frequency of antibodies with binding specificity for dead, dying, and senescent cells, which may have been selected during the evolution of the adaptive immune system. The high potential valency of antigen-binding of polymeric IgM and an associated superior ability to interact with the early complement recognition factors, MBL and Clq, as well the absence of the capacity for activating $\mathrm{Fc} \gamma \mathrm{R}$ triggering, can provide natural $\operatorname{IgM}$ with unique properties for enhancing the interactions between apoptotic cell and phagocyte. Although the postulated role of natural IgM in the development of a cellular synapse between apoptotic cells and phagocytes is still speculative, there is evidence that these autoantibodies may mediate specific anti-inflammatory signaling pathways.

Based on recent findings regarding the potential roles of natural antibodies, there may be prognostic and diagnostic value in the monitoring of levels of natural IgM to specific apoptosisassociated antigens to better predict clinical manifestations and for evaluating response to therapeutic interventions. In the light of the above described observations, it is appealing to envision future therapeutic strategies based on harnessing the properties of natural antibodies. As natural IgM may act to influence pathogenesis through suppression of inflammatory responses from innate immune cells, this therapeutic approach would be hypothesized to be effective in a range of diseases. In fact, therapeutic intravenous immunoglobulin treatments are already in development that take advantage of the properties of natural IgM (Bayry et al., 2011), although a monoclonal strategy could provide a safer and more effective approach. Finally, advances in our understanding of the roles of natural antibodies may have implications for $\mathrm{B}$-cell targeted therapies as these biopharmaceuticals may also deplete B-1 cells and reduce the expression of protective natural antibodies.

a key to immune defense against pathogen invasion. Springer Semin. Immunopathol. 26, 347-362.

Bayry, J., Negi, V. S., and Kaveri, S. V. (2011). Intravenous immunoglobulin therapy in rheumatic diseases. Nat. Rev. Rheumatol. 7, 349-359.

Bili, A., Moss, A. J., Francis, C. W. Zareba, W., Watelet, L. F., and Sanz, I. (2000). Anticardiolipin antibodies and recurrent coronary events: a prospective study of 1150 patients. Thrombogenic factors, and recurrent coronary events investigators. Circulation 102, 1258-1263.

Binder, C. J., Horkko, S., Dewan, A., Chang, M. K., Kieu, E. P., Goodyear, C. S., Shaw, P. X., Palinski, W., Witztum, J. L., and Silverman, G. J. (2003). Pneumococcal vaccination decreases atherosclerotic lesion formation: molecular mimicry between Streptococcus pneumoniae and oxidized LDL. Nat. Med. 9, 736-743.
Boes, M., Prodeus, A. P., Schmidt, T., Carroll, M. C., and Chen, J. (1998). A critical role of natural immunoglobulin $\mathrm{M}$ in immediate defense against systemic bacterial infection. J. Exp. Med. 188, 2381-2386.

Boes, M., Schmidt, T., Linkemann, K., Beaudette, B. C., MarshakRothstein, A., and Chen, J. (2000). Accelerated development of IgG autoantibodies and autoimmune disease in the absence of secreted IgM. Proc. Natl. Acad. Sci. U.S.A. 97, 1184-1189.

Bos, N. A., Kimura, H., Meeuwsen, C. G., De Visser, H., Hazenberg, M. P., Wostmann, B. S., Pleasants, J. R., Benner, R., and Marcus, D. M. (1989). Serum immunoglobulin levels and naturally occurring antibodies against carbohydrate antigens in germ-free BALB/c mice fed chemically defined ultrafiltered diet. Eur. J. Immunol. 19, 2335-2339. 
Botto, M., and Walport, M. J. (2002). C1q, autoimmunity and apoptosis. Immunobiology 205, 395-406.

Carrero, J. J., Hua, X., Stenvinkel, P., Qureshi, A. R., Heimburger, O., Barany, P., Lindholm, B., and Frostegard, J. (2009). Low levels of IgM antibodies against phosphorylcholine-A increase mortality risk in patients undergoing haemodialysis. Nephrol. Dial. Transplant. 24, 3454-3460.

Casali, P., and Notkins, A. L. (1989). CD5+ B lymphocytes, polyreactive antibodies and the human Bcell repertoire. Immunol. Today 10, 364-368.

Cesena, F. H., Dimayuga, P. C., Yano, J., Zhao, X., Kirzner, J., Zhou, J., Chan, L. F., Lio, W. M., Cercek, B., Shah, P. K., and Chyu, K. Y. (2012). Immune-modulation by polyclonal IgM treatment reduces atherosclerosis in hypercholesterolemic apoE-/mice. Atherosclerosis 220, 59-65.

Chen, Y., Khanna, S., Goodyear, C. S., Park, Y. B., Raz, E., Thiel, S., Gronwall, C., Vas, J., Boyle, D. L., Corr, M., Kono, D. H., and Silverman, G. J. (2009a). Regulation of dendritic cells and macrophages by an anti-apoptotic cell natural antibody that suppresses TLR responses and inhibits inflammatory arthritis. J. Immunol. 183, 1346-1359.

Chen, Y., Park, Y. B., Patel, E., and Silverman, G. J. (2009b). IgM antibodies to apoptosis-associated determinants recruit $\mathrm{Clq}$ and enhance dendritic cell phagocytosis of apoptotic cells. J. Immunol. 182, 6031-6043.

Chen, Z. J., Wheeler, C. J., Shi, W., Wu, A. J., Yarboro, C. H., Gallagher, M., and Notkins, A. L. (1998). Polyreactive antigen-binding B cells are the predominant cell type in the newborn B cell repertoire. Eur. J. Immunol. 28, 989-994.

Choi, Y. S., Dieter, J. A., Rothaeusler, K., Luo, Z., and Baumgarth, N. (2012). $\mathrm{B}-1$ cells in the bone marrow are a significant source of natural IgM. Eur. J. Immunol. 42, 120-129.

Chou, M. Y., Fogelstrand, L., Hartvigsen, K., Hansen, L. F., Woelkers, D., Shaw, P. X., Choi, J., Perkmann, T., Backhed, F., Miller, Y. I., Horkko, S., Corr, M., Witztum, J. L., and Binder, C. J. (2009). Oxidation-specific epitopes are dominant targets of innate natural antibodies in mice and humans. J. Clin. Invest. 119, 1335-1349.

Cocca, B. A., Seal, S. N., D'agnillo, P., Mueller, Y. M., Katsikis, P. D., Rauch, J., Weigert, M., and Radic, M. Z. (2001). Structural basis for autoantibody recognition of phosphatidylserine-beta 2 glycoprotein I and apoptotic cells. Proc. Natl. Acad. Sci. U.S.A. 98, 13826-13831.

Cox, K. O., and Hardy, S. J. (1985). Autoantibodies against mouse bromelain-modified RBC are specifically inhibited by a common membrane phospholipid, phosphatidylcholine. Immunology 55, 263-269.

Czajkowsky, D. M., and Shao, Z. (2009). The human IgM pentamer is a mushroom-shaped molecule with a flexural bias. Proc. Natl. Acad. Sci. U.S.A. 106, 14960-14965.

de Faire, U., and Frostegard, J. (2009). Natural antibodies against phosphorylcholine in cardiovascular disease. Ann. N. Y. Acad. Sci. 1173, 292-300.

deCathelineau, A. M., and Henson, P. M. (2003). The final step in programmed cell death: phagocytes carry apoptotic cells to the grave. Essays Biochem. 39, 105-117.

Devitt, A., and Marshall, L. J. (2011). The innate immune system and the clearance of apoptotic cells. J. Leukoc. Biol. 90, 447-457.

Diamond, B., Katz, J. B., Paul, E., Aranow, C., Lustgarten, D., and Scharff, M. D. (1992). The role of somatic mutation in the pathogenic antiDNA response. Annu. Rev. Immunol. 10, 731-757.

Diamond, B., and Scharff, M. D. (1984). Somatic mutation of the T15 heavy chain gives rise to an antibody with autoantibody specificity. Proc. Natl. Acad. Sci. U.S.A. 81, 5841-5844.

Dooley, H., and Flajnik, M. F. (2006). Antibody repertoire development in cartilaginous fish. Dev. Comp. Immunol. 30, 43-56.

Ehrenstein, M. R., Cook, H. T., and Neuberger, M. S. (2000). Deficiency in serum immunoglobulin ( $\mathrm{Ig}) \mathrm{M}$ predisposes to development of IgG autoantibodies. J. Exp. Med. 191, 1253-1258.

Eriksson, U. K., Sjoberg, B. G., Bennet, A. M., De Faire, U., Pedersen, N. L., and Frostegard, J. (2010). Low levels of antibodies against phosphorylcholine in Alzheimer's disease. $J$. Alzheimers Dis. 21, 577-584.

Feng, X., Zhang, Y., Xu, R., Xie, X., Tao, L., Gao, H., Gao, Y., He, Z., and Wang, H. (2010). Lipopolysaccharide up-regulates the expression of Fcalpha/mu receptor and promotes the binding of oxidized lowdensity lipoprotein and its IgM antibody complex to activated human macrophages. Atherosclerosis 208, 396-405.

Fiskesund, R., Stegmayr, B., Hallmans, G., Vikstrom, M., Weinehall, L., De Faire, U., and Frostegard, J. (2010).
Low levels of antibodies against phosphorylcholine predict development of stroke in a population-based study from northern Sweden. Stroke 41, 607-612.

Forger, F., Matthias, T., Oppermann, M., Becker, H., and Helmke, K. (2004). Clinical significance of anti-dsDNA antibody isotypes: IgG/IgM ratio of anti-dsDNA antibodies as a prognostic marker for lupus nephritis. Lupus 13, 36-44.

Fraser, D. A., Laust, A. K., Nelson, E. L. and Tenner, A. J. (2009). Clq differentially modulates phagocytosis and cytokine responses during ingestion of apoptotic cells by human monocytes, macrophages, and dendritic cells. J. Immunol. 183, 6175-6185.

Friedman, P., Horkko, S., Steinberg, D. Witztum, J. L., and Dennis, E. A. (2002). Correlation of antiphospholipid antibody recognition with the structure of synthetic oxidized phospholipids. Importance of Schiff base formation and aldol condensation. J. Biol. Chem. 277, 7010-7020.

Fu, M., Fan, P. S., Li, W., Li, C. X., Xing, Y., An, J. G., Wang, G., Fan, X. L., Gao, T. W., Liu, Y. F., and Ikeda, S. (2007) Identification of poly-reactive natural $\operatorname{IgM}$ antibody that recognizes late apoptotic cells and promotes phagocytosis of the cells. Apoptosis $12,355-362$.

Fukumoto, M., Shoji, T., Emoto, M., Kawagishi, T., Okuno, Y., and Nishizawa, Y. (2000). Antibodies against oxidized LDL and carotid artery intima-media thickness in a healthy population. Arterioscler. Thromb. Vasc. Biol. 20, 703-707.

Garrido-Sanchez, L., Chinchurreta, P., Garcia-Fuentes, E., Mora, M., and Tinahones, F. J. (2010). A higher level of IgM anti-oxidized LDL antibodies is associated with a lower severity of coronary atherosclerosis in patients on statins. Int. J. Cardiol. 145, 263-264.

Gearhart, P. J., Sigal, N. H., and Klinman, N. R. (1977). The monoclonal anti-phosphorylcholine antibody response in several murine strains: genetic implications of a diverse repertoire. J. Exp. Med. 145, 876-891.

Ghosn, E. E., Sadate-Ngatchou, P., Yang, Y., and Herzenberg, L. A. (2011). Distinct progenitors for B-1 and B2 cells are present in adult mouse spleen. Proc. Natl. Acad. Sci. U.S.A. 108, 2879-2884.

Gray, M., Miles, K., Salter, D., Gray, D., and Savill, J. (2007). Apoptotic cells protect mice from autoimmune inflammation by the induction of regulatory B cells. Proc. Natl. Acad. Sci. U.S.A. 104, 14080-14085.

Griffin, D. O., Holodick, N. E., and Rothstein, T. L. (2011). Human B1 cells in umbilical cord and adult peripheral blood express the novel phenotype CD20+ CD27+ CD43+ CD70. J. Exp. Med. 208, 67-80.

Gronlund, H., Hallmans, G., Jansson, J. H., Boman, K., Wikstrom, M., De Faire, U., and Frostegard, J. (2009). Low levels of IgM antibodies against phosphorylcholine predict development of acute myocardial infarction in a population-based cohort from northern Sweden. Eur. J. Cardiovasc. Prev. Rehabil. 16, 382-386.

Gronwall, C., Akhter, E., Oh, C., Burlingame, R. W., Petri, M., and Silverman, G. J. (2012). IgM autoantibodies to distinct apoptosisassociated antigens correlate with protection from cardiovascular events and renal disease in patients with SLE. Clin. Immunol. 142, 390-398.

Haas, K. M., Poe, J. C., Steeber, D. A., and Tedder, T. F. (2005). B-1a and B$1 \mathrm{~b}$ cells exhibit distinct developmental requirements and have unique functional roles in innate and adaptive immunity to $S$. pneumoniae. Immunity 23, 7-18.

Hardy, R. R., Carmack, C. E., Shinton, S. A., Riblet, R. J., and Hayakawa, K. (1989). A single VH gene is utilized predominantly in antiBrMRBC hybridomas derived from purified Ly-1 B cells. Definition of the VH11 family. J. Immunol. 142, 3643-3651.

Hardy, R. R., and Hayakawa, K. (2005). Development of B cells producing natural autoantibodies to thymocytes and senescent erythrocytes. Springer Semin. Immunopathol. 26, 363-375.

Haury, M., Sundblad, A., Grandien, A., Barreau, C., Coutinho, A., and Nobrega, A. (1997). The repertoire of serum IgM in normal mice is largely independent of external antigenic contact. Eur. J. Immunol. 27, 1557-1563.

Hayakawa, K., Asano, M., Shinton, S. A., Gui, M., Allman, D., Stewart, C. L., Silver, J., and Hardy, R. R. (1999). Positive selection of natural autoreactive B cells. Science 285, 113-116.

Hayakawa, K., Hardy, R. R., and Herzenberg, L. A. (1986). Peritoneal Ly-1 B cells: genetic control, autoantibody production, increased lambda light chain expression. Eur. J. Immunol. 16, 450-456.

Herzenberg, L. A., Baumgarth, N., and Wilshire, J. A. (2000). B-1 cell origins and $\mathrm{VH}$ repertoire determination. 
Curr. Top. Microbiol. Immunol. 252, 3-13.

Hofmann, M. A., Drury, S., Fu, C., Qu, W., Taguchi, A., Lu, Y., Avila, C., Kambham, N., Bierhaus, A., Nawroth, P., Neurath, M. F., Slattery, T., Beach, D., Mcclary, J., Nagashima, M., Morser, J., Stern, D., and Schmidt, A. M. (1999). RAGE mediates a novel proinflammatory axis: a central cell surface receptor for $\$ 100 /$ calgranulin polypeptides. Cell 97, 889-901.

Holodick, N. E., Tumang, J. R., and Rothstein, T. L. (2010). Immunoglobulin secretion by $\mathrm{B} 1$ cells: differential intensity and IRF4-dependence of spontaneous IgM secretion by peritoneal and splenic B1 cells. Eur. J. Immunol. 40, 3007-3016.

Honda, S., Kurita, N., Miyamoto, A., Cho, Y., Usui, K., Takeshita, K., Takahashi, S., Yasui, T., Kikutani, H., Kinoshita, T., Fujita, T., Tahara-Hanaoka, S., Shibuya, K., and Shibuya, A. (2009). Enhanced humoral immune responses against T-independent antigens in $\mathrm{Fc}$ alpha/muR-deficient mice. Proc. Natl. Acad. Sci. U.S.A. 106, 11230-11235.

Huynh, M. L., Fadok, V. A., and Henson, P. M. (2002). Phosphatidylserinedependent ingestion of apoptotic cells promotes TGF-betal secretion and the resolution of inflammation. J. Clin. Invest. 109, 41-50.

Jiang, C., Zhao, M. L., Scearce, R. M., and Diaz, M. (2011). Activation-induced deaminase-deficient MRL/lpr mice secrete high levels of protective antibodies against lupus nephritis. Arthritis Rheum. 63, 1086-1096.

Kaetzel, C. S. (2005). The polymeric immunoglobulin receptor: bridging innate and adaptive immune responses at mucosal surfaces. Immunol. Rev. 206, 83-99.

Kantor, A. B., Merrill, C. E., Herzenberg, L. A., and Hillson, J. L. (1997). An unbiased analysis of $\mathrm{V}(\mathrm{H})-\mathrm{D}-\mathrm{J}(\mathrm{H})$ sequences from $\mathrm{B}-1 \mathrm{a}, \mathrm{B}-\mathrm{lb}$, and conventional B cells. J. Immunol. 158, 1175-1186.

Karvonen, J., Paivansalo, M., Kesaniemi, Y. A., and Horkko, S. (2003). Immunoglobulin $\mathrm{M}$ type of autoantibodies to oxidized low-density lipoprotein has an inverse relation to carotid artery atherosclerosis. Circulation 108, 2107-2112.

Kim, J. (2010). Identification of a human monoclonal natural IgM antibody that recognizes early apoptotic cells and promotes phagocytosis. Hybridoma (Larchmt) 29, 275-281.
Kono, H., and Rock, K. L. (2008). How dying cells alert the immune system to danger. Nat. Rev. Immunol. 8, 279-289.

Korb, L. C., and Ahearn, J. M. (1997). Clq binds directly and specifically to surface blebs of apoptotic human keratinocytes: complement deficiency and systemic lupus erythematosus revisited. J. Immunol. 158, 4525-4528.

Kroese, F. G., and Bos, N. A. (1999). Peritoneal B-1 cells switch in vivo to IgA and these IgA antibodies can bind to bacteria of the normal intestinal microflora. Curr. Top. Microbiol. Immunol. 246, 343-349; discussion 350.

Kroese, F. G., Butcher, E. C., Stall, A. M., Lalor, P. A., Adams, S., and Herzenberg, L. A. (1989). Many of the IgA producing plasma cells in murine gut are derived from selfreplenishing precursors in the peritoneal cavity. Int. Immunol. 1, 75-84.

Kulik, L., Fleming, S. D., Moratz, C., Reuter, J. W., Novikov, A., Chen, K., Andrews, K. A., Markaryan, A., Quigg, R. J., Silverman, G. J., Tsokos, G. C., and Holers, V. M. (2009). Pathogenic natural antibodies recognizing annexin IV are required to develop intestinal ischemia-reperfusion injury. $J$. Immunol. 182, 5363-5373.

Lewis, M. J., and Botto, M. (2006). Complement deficiencies in humans and animals: links to autoimmunity. Autoimmunity 39, 367-378.

Lewis, M. J., Malik, T. H., Ehrenstein, M. R., Boyle, J. J., Botto, M., and Haskard, D. O. (2009). Immunoglobulin $\mathrm{M}$ is required for protection against atherosclerosis in low-density lipoprotein receptordeficient mice. Circulation 120, 417-426.

Li, Q. Z., Xie, C., Wu, T., Mackay, M., Aranow, C., Putterman, C., and Mohan, C. (2005). Identification of autoantibody clusters that best predict lupus disease activity using glomerular proteome arrays. J. Clin. Invest. 115, 3428-3439.

Litvack, M. L., Djiadeu, P., Renganathan, S. D., Sy, S., Post, M., and Palaniyar, N. (2010). Natural IgM and innate immune collectin SP-D bind to late apoptotic cells and enhance their clearance by alveolar macrophages in vivo. Mol. Immunol. 48, 37-47.

Litvack, M. L., Post, M., and Palaniyar, N. (2011). IgM promotes the clearance of small particles and apoptotic microparticles by macrophages. PLoS ONE 6, e17223. doi:10.1371/journal.pone.0017223
Madi, A., Hecht, I., Bransburg-Zabary, S., Merbl, Y., Pick, A., ZuckerToledano, M., Quintana, F. J., Tauber, A. I., Cohen, I. R., and Ben-Jacob, E. (2009). Organization of the autoantibody repertoire in healthy newborns and adults revealed by system level informatics of antigen microarray data. Proc. Natl. Acad. Sci. U.S.A. 106, 14484-14489.

Martin, F., and Kearney, J. F. (2002). Marginal-zone B cells. Nat. Rev. Immunol. 2, 323-335.

Martin, F., Oliver, A. M., and Kearney, J. F. (2001). Marginal zone and B1 $\mathrm{B}$ cells unite in the early response against $\mathrm{T}$-independent blood-borne particulate antigens. Immunity 14, 617-629.

Mehrani, T., and Petri, M. (2011). IgM anti-beta2 glycoprotein I is protective against lupus nephritis and renal damage in systemic lupus erythematosus. J. Rheumatol. 38, 450-453.

Merbl, Y., Zucker-Toledano, M., Quintana, F. J., and Cohen, I. R. (2007). Newborn humans manifest autoantibodies to defined self molecules detected by antigen microarray informatics. J. Clin. Invest. 117 712-718.

Mercolino, T. J., Arnold, L. W., and Haughton, G. (1986). Phosphatidyl choline is recognized by a series of Ly-1+ murine B cell lymphomas specific for erythrocyte membranes. $J$. Exp. Med. 163, 155-165.

Mercolino, T. J., Locke, A. L., Afshari, A., Sasser, D., Travis, W. W., Arnold, L. W., and Haughton, G. (1989). Restricted immunoglobulin variable region gene usage by normal Ly-1 (CD5+) B cells that recognize phosphatidyl choline. J. Exp. Med. 169, 1869-1877.

Mi, Q. S., Zhou, L., Schulze, D. H., Fischer, R. T., Lustig, A., Rezanka, L. J., Donovan, D. M., Longo, D. L., and Kenny, J. J. (2000). Highly reduced protection against Streptococcus pneumoniae after deletion of a single heavy chain gene in mouse. Proc. Natl. Acad. Sci. U.S.A. 97, 6031-6036.

Navratil, J. S., Watkins, S. C., Wisnieski, J. J., and Ahearn, J. M. (2001). The globular heads of $\mathrm{Clq}$ specifically recognize surface blebs of apoptotic vascular endothelial cells. J. Immunol. 166, 3231-3239.

Notley, C. A., Brown, M. A., Wright, G. P., and Ehrenstein, M. R. (2011) Natural IgM is required for suppression of inflammatory arthritis by apoptotic cells. J. Immunol. 186, 4967-4972.
Ochsenbein, A. F., Fehr, T., Lutz, C., Suter, M., Brombacher, F., Hengartner, H., and Zinkernagel, R. M. (1999). Control of early viral and bacterial distribution and disease by natural antibodies. Science 286 , 2156-2159.

Ogden, C. A., Decathelineau, A., Hoffmann, P. R., Bratton, D., Ghebrehiwet, B., Fadok, V. A., and Henson, P. M. (2001). Clq and mannose binding lectin engagement of cell surface calreticulin and CD91 initiates macropinocytosis and uptake of apoptotic cells. J. Exp. Med. 194, 781-795.

Ogden, C. A., Kowalewski, R., Peng, Y., Montenegro, V., and Elkon, K. B. (2005). IGM is required for efficient complement mediated phagocytosis of apoptotic cells in vivo. Autoimmunity 38, 259-264.

Padilla, N. D., Ciurana, C., Van Oers, J., Ogilvie, A. C., and Hack, C. E. (2004). Levels of natural IgM antibodies against phosphorylcholine in healthy individuals and in patients undergoing isolated limb perfusion. J. Immunol. Methods 293, 1-11.

Paidassi, H., Tacnet-Delorme, P., Garlatti, V., Darnault, C., Ghebrehiwet, B., Gaboriaud, C., Arlaud, G. J., and Frachet, P. (2008). C1q binds phosphatidylserine and likely acts as a multiligand-bridging molecule in apoptotic cell recognition. $J$. Immunol. 180, 2329-2338.

Peng, Y., Kowalewski, R., Kim, S., and Elkon, K. B. (2005). The role of IgM antibodies in the recognition and clearance of apoptotic cells. Mol. Immunol. 42, 781-787.

Perkins, S. J., Nealis, A. S., Sutton, B. J., and Feinstein, A. (1991). Solution structure of human and mouse immunoglobulin $\mathrm{M}$ by synchrotron X-ray scattering and molecular graphics modelling. A possible mechanism for complement activation. J. Mol. Biol. 221, 1345-1366.

Perlmutter, R. M., Kearney, J. F., Chang, S. P., and Hood, L. E. (1985). Developmentally controlled expression of immunoglobulin VH genes. Science 227, 1597-1601.

Pillai, S., Cariappa, A., and Moran, S. T. (2004). Positive selection and lineage commitment during peripheral Blymphocyte development. Immunol. Rev. 197, 206-218.

Quartier, P., Potter, P. K., Ehrenstein, M. R., Walport, M. J., and Botto, M. (2005). Predominant role of IgMdependent activation of the classical pathway in the clearance of dying cells by murine bone marrowderived macrophages in vitro. Eur. J. Immunol. 35, 252-260. 
Ravichandran, K. S., and Lorenz, U. (2007). Engulfment of apoptotic cells: signals for a good meal. Nat. Rev. Immunol. 7, 964-974.

Rouhl, R. P., Van Oostenbrugge, R. J., Theunissen, R. O., Knottnerus, I. L., Staals, J., Henskens, L. H., Kroon, A. A., De Leeuw, P. W., Lodder, J., Tervaert, J. W., and Damoiseaux, J. G. (2010). Autoantibodies against oxidized low-density lipoprotein in cerebral small vessel disease. Stroke 41, 2687-2689.

Rovere, P., Manfredi, A. A., Vallinoto, C., Zimmermann, V. S., Fascio, U., Balestrieri, G., Ricciardi-Castagnoli, P., Rugarli, C., Tincani, A., and Sabbadini, M. G. (1998). Dendritic cells preferentially internalize apoptotic cells opsonized by anti-beta2glycoprotein I antibodies. J. Autoimmun. 11, 403-411.

Rowley, B., Tang, L., Shinton, S., Hayakawa, K., and Hardy, R. R. (2007). Autoreactive B-1 B cells: constraints on natural autoantibody $B$ cell antigen receptors. J. Autoimmun. 29, 236-245.

Satow, Y., Cohen, G. H., Padlan, E. A., and Davies, D. R. (1986). Phosphocholine binding immunoglobulin Fab McPC603. An X-ray diffraction study at 2.7 A. J. Mol. Biol. 190, 593-604.

Scaffidi, P., Misteli, T., and Bianchi, M.E. (2002). Release of chromatin protein HMGB1 by necrotic cells triggers inflammation. Nature 418, 191-195.

Seidl, K. J., Mackenzie, J. D., Wang, D., Kantor, A. B., Kabat, E. A., and Herzenberg, L. A. (1997). Frequent occurrence of identical heavy and light chain Ig rearrangements. Int. Immunol. 9, 689-702.

Shaw, P. X., Goodyear, C. S., Chang, M. K., Witztum, J. L., and Silverman, G. J. (2003). The autoreactivity of anti-phosphorylcholine antibodies for atherosclerosisassociated neo-antigens and apoptotic cells. J. Immunol. 170, 6151-6157.

Shaw, P. X., Horkko, S., Chang, M. K., Curtiss, L. K., Palinski, W., Silverman, G. J., and Witztum, J. L. (2000). Natural antibodies with the T15 idiotype may act in atherosclerosis, apoptotic clearance, and protective immunity. J. Clin. Invest. 105, 1731-1740.
Shi, Y., Evans, J. E., and Rock, K. L. (2003). Molecular identification of a danger signal that alerts the immune system to dying cells. Nature 425 , 516-521.

Shibuya, A., Sakamoto, N., Shimizu, Y., Shibuya, K., Osawa, M., Hiroyama, T., Eyre, H. J., Sutherland, G. R., Endo, Y., Fujita, T., Miyabayashi, T., Sakano, S., Tsuji, T., Nakayama, E., Phillips, J. H., Lanier, L. L., and Nakauchi, H. (2000). Fc alpha/mu receptor mediates endocytosis of IgM-coated microbes. Nat. Immunol. 1, 441-446.

Shima, H., Takatsu, H., Fukuda, S., Ohmae, M., Hase, K., Kubagawa, H., Wang, J. Y., and Ohno, H. (2010). Identification of TOSO/FAIM 3 as an $\mathrm{Fc}$ receptor for IgM. Int. Immunol. 22, 149-156.

Shulzhenko, N., Morgun, A., Hsiao, W., Battle, M., Yao, M., Gavrilova, O., Orandle, M., Mayer, L., Macpherson, A. J., Mccoy, K. D., Fraser-Liggett, C., and Matzinger, P. (2011). Crosstalk between B lymphocytes, microbiota and the intestinal epithelium governs immunity versus metabolism in the gut. Nat. Med. 17, 1585-1593.

Sigal, N. H., Gearhart, P. J., and Klinman, N. R. (1975). The frequency of phosphorylcholine-specific B cells in conventional and germfree BALB/C mice. J. Immunol. 114, 1354-1358.

Silverman, G. J., Gronwall, C., Vas, J., and Chen, Y. (2009). Natural autoantibodies to apoptotic cell membranes regulate fundamental innate immune functions and suppress inflammation. Discov. Med. 8, 151-156.

Silverman, G. J., Srikrishnan, R., Germar, K., Goodyear, C. S., Andrews, K. A., Ginzler, E. M., and Tsao, B. P. (2008). Genetic imprinting of autoantibody repertoires in systemic lupus erythematosus patients. Clin. Exp. Immunol. 153, 102-116.

Sorice, M., Circella, A., Misasi, R., Pittoni, V., Garofalo, T., Cirelli, A., Pavan, A., Pontieri, G. M., and Valesini, G. (2000). Cardiolipin on the surface of apoptotic cells as a possible trigger for antiphospholipids antibodies. Clin. Exp. Immunol. 122, 277-284.

Stoehr, A. D., Schoen, C. T., Mertes, M. M., Eiglmeier, S., Holecska, V., Lorenz, A. K., Schommartz, T.,
Schoen, A. L., Hess, C., Winkler, A., Wardemann, H., and Ehlers, M. (2011). TLR9 in peritoneal B-1b cells is essential for production of protective self-reactive IgM to control Th17 cells and severe autoimmunity. J. Immunol. 187, 2953-2965.

Stoel, M., Jiang, H. Q., Van Diemen, C. C., Bun, J. C., Dammers, P. M., Thurnheer, M. C., Kroese, F. G., Cebra, J. J., and Bos, N. A. (2005). Restricted IgA repertoire in both B-1 and B-2 cell-derived gut plasmablasts. J. Immunol. 174 1046-1054.

Stuart, L. M., Takahashi, K., Shi, L., Savill, J., and Ezekowitz, R. A. (2005) Mannose-binding lectin-deficient mice display defective apoptotic cell clearance but no autoimmune phenotype. J. Immunol. 174, 3220-3226.

$\mathrm{Su}, \mathrm{J}$. , Hua, X., Concha, H., Svenungsson, E., Cederholm, A., and Frostegard, J. (2008). Natural antibodies against phosphorylcholine as potential protective factors in SLE. Rheumatology (Oxford) 47, 1144-1150.

Tung, J. W., Mrazek, M. D., Yang, Y., and Herzenberg, L. A. (2006). Phenotypically distinct $\mathrm{B}$ cell development pathways map to the three $B$ cell lineages in the mouse. Proc. Natl. Acad. Sci. U.S.A. 103, 6293-6298.

Tuominen, A., Miller, Y. I., Hansen, L. F., Kesaniemi, Y. A., Witztum, J. L., and Horkko, S. (2006). A natural antibody to oxidized cardiolipin binds to oxidized low-density lipoprotein, apoptotic cells, and atherosclerotic lesions. Arterioscler. Thromb. Vasc. Biol. 26, 2096-2102.

Vasconcellos, R., Nobrega, A., Haury, M., Viale, A. C., and Coutinho, A. (1998). Genetic control of natural antibody repertoires: I. IgH, MHC and TCR beta loci. Eur. J. Immunol. 28, 1104-1115.

Vire, B., David, A., and Wiestner, A. (2011). TOSO, the Fcmicro receptor, is highly expressed on chronic lymphocytic leukemia B cells, internalizes upon IgM binding, shuttles to the lysosome, and is downregulated in response to TLR activation. J. Immunol. 187, 4040-4050.

Wang, H., and Clarke, S. H. (2004). Positive selection focuses the VH12 B-cell repertoire towards a single B1 specificity with survival function. Immunol. Rev. 197, 51-59.
Wellmann, U., Letz, M., Herrmann, M., Angermuller, S., Kalden, J. R., and Winkler, T. H. (2005). The evolution of human antidouble-stranded DNA autoantibodies. Proc. Natl. Acad. Sci. U.S.A. 102, 9258-9263.

Werwitzke, S., Trick, D., Kamino, K., Matthias, T., Kniesch, K., Schlegelberger, B., Schmidt, R. E., and Witte, T. (2005). Inhibition of lupus disease by anti-double-stranded DNA antibodies of the IgM isotype in the (NZB x NZW)F1 mouse. Arthritis Rheum. 52, 3629-3638.

Witte, T. (2008). IgM antibodies against dsDNA in SLE. Clin. Rev. Allergy Immunol. 34, 345-347.

Witte, T., Hartung, K., Sachse, C. Matthias, T., Fricke, M., Deicher, H., Kalden, J. R., Lakomek, H. J., Peter, H. H., and Schmidt, R. E. (1998). IgM anti-dsDNA antibodies in systemic lupus erythematosus: negative association with nephritis. SLE Study Group. Rheumatol. Int. 18, 85-91.

Zhou, Z. H., Zhang, Y., Hu, Y. F., Wahl, L. M., Cisar, J. O., and Notkins, A. L. (2007). The broad antibacterial activity of the natural antibody repertoire is due to polyreactive antibodies. Cell Host Microbe 1, 51-61.

Conflict of Interest Statement: The authors declare that the research was conducted in the absence of any commercial or financial relationships that could be construed as a potential conflict of interest.

Received: 17 January 2012; accepted: 16 March 2012; published online: 04 April 2012.

Citation: Grönwall C, Vas J and Silverman GJ (2012) Protective roles of natural IgM antibodies. Front. Immun. 3:66. doi: 10.3389/fimmu.2012.00066

This article was submitted to Frontiers in $B$ Cell Biology, a specialty of Frontiers in Immunology.

Copyright $\odot 2012$ Grönwall, Vas and Silverman. This is an open-access article distributed under the terms of the Creative Commons Attribution Non Commercial License, which permits noncommercial use, distribution, and reproduction in other forums, provided the original authors and source are credited. 